\title{
The Eurasian Economic Union: A case of reproductive integration?
}

\author{
Sean P. Roberts
}

School of Social, Historical and Literary Studies, University of Portsmouth,

Portsmouth, United Kingdom

Address: Milldam, Burnaby Road, Portsmouth, Hants PO1 3AS

Email: sean.roberts@port.ac.uk

Arkady Moshes

The EU's Eastern Neighbourhood and Russia research programme, The Finnish Institute of International Affairs, Helsinki, Finland

Address: The Finnish Institute of International Affairs, P.O. Box 400, FI-00161, Helsinki, Finland

Email: arkady.moshes@fiia.fi 


\title{
The Eurasian Economic Union: A case of reproductive integration?
}

\author{
The Eurasian Economic Union (EAEU) appeared in January 2015 as the latest \\ and most ambitious attempt at reconnecting the post-Soviet space. Building on \\ the Customs Union between Belarus, Russia and Kazakhstan (2010), and \\ successfully extending membership to Armenia and Kyrgyzstan (2015), the \\ EAEU not only connects a market of over 182 million people, but has the stated \\ aim of utilising European Union (EU) experience to achieve deep integration in a \\ fraction of the time. Based on original fieldwork conducted in Armenia, Belarus, \\ Kazakhstan and Russia, this article examines the kind of integration project \\ currently under construction, as well as the EAEU's ability to make a significant \\ impact in the region. As argued, despite early achievements, the EAEU is very \\ much limited to reproducing sovereignty rather than transforming it, marking a \\ clear disconnect between rhetoric and reality. Moreover, when viewed from the \\ perspective of the three 'I's - institutions, identity and international context - \\ even this modest reality faces significant barriers.
}

Keywords: Eurasian; economic; Russia; integration; sovereignty

\section{INTRODUCTION}

The Eurasian Economic Union (EAEU) officially appeared as a regional organisation on 1 January 2015, following the signing of a landmark treaty by the Presidents of Belarus, Kazakhstan and Russia in Astana, Kazakhstan, on 29 May 2014. As a territory encompassing over 20 million square kilometres and with a market size of just over 182 million people, the EAEU represents the most significant development in the region's economic and political landscape since the European Union's (EU) eastern expansion in the early 2000s. The addition of Armenia in January 2015, following its earlier rejection of an EU association agreement, and Kyrgyzstan in May 2015, has given Eurasian integration impetus and a feeling of genuine optimism in a part of the world that has been slow to realise the economic integration imperative.

But, despite the importance of EAEU, the kind of integration member states are attempting and, by extension, the implications of this integration, are less than clear. Distracted by the Ukraine crisis, western media have largely ignored the EAEU, while the academic community remains divided on the prospects of the project. Recent studies do little to clarify the picture, either dismissing the EAEU out of hand as a thinly veiled manifestation of Russia's geopolitical ambitions (Adomeit 2012; Krickovic 2014) or taking a cautiously optimistic approach, but none the less viewing further integration as 
largely inevitable (Dutkiewicz 2015; Dragneva and Wolczuk 2012a; Libman and Vonkurov 2012; Sakwa 2015). This latter literature echoes high-level statements coming from EAEU leaders, which emphasise the serious, long-term nature of the project but also its ambitious goals of transforming the region's economic and political relations. Indeed, the theme of 'transformation' is one that subtly runs through official discourse, where references to the supranational component of the EAEU and analogies to the EU are common. Some scholars have already noted how Eurasian integration appears to buck the trend of second wave regionalism in its efforts to imitate the EU and pursue ‘deep integration' (Dragneva and Wolczuk 2012a, p. 220).

It is against this backdrop that this article seeks to make sense of Eurasian economic integration. What kind of integration are member states attempting? Can the EAEU serve to transform the region's economic and political relations? And what are the prospects of this actually happening in the medium to long-term? This article attempts to answer these questions utilising original research conducted just before and after the official unveiling of the EAEU in January 2015. This research includes over 30 face-toface, in-depth interviews conducted in Armenia, Belarus, Kazakhstan and Russia with country experts and EAEU stakeholders, including representatives from the newly formed Eurasian Economic Commission as well as Foreign and Economic ministries in each state. ${ }^{1}$

The organisation of this article is as follows. The first part briefly outlines the development of the EAEU and the debates on the kind of integration currently underway. The second section outlines the analytical framework used in this article to gauge the transformative potential of the EAEU, with the final three sections exploring the three I's of Eurasian integration - institutions, identity and the international context.

This article contributes to existing literature in the following ways. First, unlike most research on the subject of Eurasian integration, this article is based on the first hand views of those individuals actually involved in the integration process in four of the five EAEU member states, helping to ground the academic debate in a much-needed empirical reality. Second, this article revives and older but important analytical distinction between 'transformative' and 'reproductive' regionalism (Schmitter 2004) allowing for a better understanding of the EAEU and providing a suitable framework for future comparative analysis on Eurasian integration.

As argued in the material that follows, the EAEU has the potential to expand its remit and bring welfare benefits to member states, as to some extent it already has. But, beneath the rhetoric, Eurasian economic integration has more modest sovereignty-

\footnotetext{
${ }^{1}$ A full list of interviewees is provided in Appendix 1. However, for the purposes of protecting the identity of individuals, all direct quotes are anonymous, with just the nationality, or in the case of the Eurasian Commission, the institutional affiliation given, e.g. Interview, Russia ,2014; Interview, Eurasian Commission, 2014, etc.). For each interview, informed consent was obtained. However, the authors of this article felt that extra ethical obligations were necessary when presenting the personal opinions of respondents.
} 
enhancing goals, placing the EAEU well in line with new regionalism projects seen in other parts of the world. Moreover, the possibility of the EAEU moving beyond the narrow interests of its member states is severely constrained by the interconnection of weak institutions, identity politics and the prevailing international context - factors long known to affect the prospects of regional integration (Nye 1968; Schmitter 1969).

\section{THE DEVELOPMENT OF EURASIAN ECONOMIC INTEGRATION}

The Eurasian Economic Union (EAEU) appeared on 1 January 2015 as the final part of a three-stage process that saw the creation of a Customs Union in 2010 and a Single Economic Space in 2012. The EAEU founding members - Belarus, Kazakhstan and Russia - quickly added Armenia to their ranks in January 2015 and by May 2015 Kyrgyzstan was all but included in the Union after its national parliament (the Jogorku Kenesh) ratified the EAEU treaty. The whole process of creating the EAEU, from the formation of the Customs Union in 2010 and up to the extension of membership to Armenia and Kyrgyzstan in 2015 has been aptly described as a 'headlong rush' (Interview, Belarus, 2014) - a rapid and intensive phase of integration that has so far covered a great deal of ground in a short period of time.

Indeed, the appearance of a functioning economic union stands in stark contrast to the stalled Commonwealth of Independent States (CIS) initiatives from the early 1990s. As early as 1993, CIS heads of state were talking of the need to reconnect former Soviet economies in order to off-set the dire economic conditions that followed the collapse of the USSR and as early as 1994, the president of Kazakhstan, Nursulan Nazarbaev, voiced the idea of a 'Eurasian Union' (Nazarbaev 1997). But, with state-building and sovereignty high on the agenda of most regional leaders at this time, these ideas were considered premature.

Eventually, three post-Soviet states - Belarus, Kazakhstan and Russia - did push the integration agenda and by 1995 an agreement on tariff-free trade was in place, with Kyrgyzstan and Tajikistan subsequently joining the trio in 1998. In 2000, these same five member states formed the Eurasian Economic Community (EurAsEC) which became the immediate predecessor to the EAEU. Although lacking a supranational element to direct the integration process, EurAsEC did provide a useful forum to eventually push for the next stage of integration. At a meeting of the EurAsEC interstate council in Minsk, Belarus, in October 2014 a decision was taken to dissolve EurAsEC into the EAEU from 1 January 2015.

The background drivers for the latest intensive phase of integration, 2010-2015, include the on-going effects of the 2008 global financial crisis, but also the broad desire shared by each member state to boost trade and investment and to increase competitiveness, in a part of the world slow to adapt to the demands of the globalized economy. Another important factor noted by some scholars is the newfound willingness of member states 
to delegate recently acquired sovereignty that was so fiercely guarded in the early postSoviet years (Glazyev and Tkachuk 2015, p. 61).

However, a more controversial aspect of the EAEU is the geopolitical component and in particular the perception that Eurasian integration is a manifestation of Russia's hegemonic ambitions in the region. A number of studies have focused on this geopolitical component in an attempt to explain the appearance of the EAEU, in particular its timing (Adomeit 2012; Krickovic 2014). From this perspective, the EAEU represents little more than an attempt to directly counter the EU's new generation of Association Agreements (Adomeit 2012) or a Russian reaction to perceived changes in the international system, at a time when western power is being called into question (Krickovic 2014, p. 523).

Despite these reservations, the creation of a more robust institutional framework has lent credibility to the idea that the EAEU is in fact a more serious project than narrowly focused realist accounts acknowledge. Excluding the Eurasian Court established in 2001 under the aegis of EurAsEC, the Eurasian Economic Commission became the first 'supranational' body designed to facilitate post-Soviet integration when it appeared in February 2012. Aside from these institutional developments, a second, visible achievement of the EAEU is its successful expansion. As mentioned, Armenia and Kyrgyzstan joined the EAEU in 2015, but there are also indications that Eurasian economic integration intends to go beyond the post-Soviet space.

On 23 December 2014, the three founding member of Belarus, Kazakhstan and Russia signed an agreement on establishing international partnerships between the EAEU and third countries (EAEU 2014) and on 29 May 2015 a free trade agreement between the EAEU and the Socialist Republic of Vietnam came into effect (EAEU 2015a). The Eurasian Commission has also set up a working group on the feasibility of a free trade zone with Egypt (Eurasian Commission 2014a), while states as far afield as Israel and India have received high level mention as prospective partners beyond the immediate region (Kremlin 2015).

There is no question that high-level statements coming from EAEU leaders have also raised expectations that this integration project is one capable of transforming the immediate region and beyond. Kazakhstan's president, Nursulan Nazarbaev has identified the EAEU with the ambitious goal of increasing economic competitiveness (Nazarbaev 2014a) in a region that lags on most economic indicators. Russia's president, Vladimir Putin, has tied integration to Russia's equally ambitious modernisation plans, in recognition that the previous economic model has 'come to an end' (Putin 2014a). In terms of regional relations, Belarus President, Aleksandr Lukashenko has identified the EAEU as the foundation for future political unity, as well as military and humanitarian cooperation (Lukashenko 2014).

In terms of the wider region, both Putin and Lukashenko have at various times framed Eurasian integration in terms of building a 'greater Europe'. This mega entity stretching from Lisbon to Vladivostok, will include both the EU and EAEU (Lukashenko 2011) 
what Lukashenko has termed 'integration of (the two) integrations' - a goal still achievable, according to Lukashenko, despite the Russia-EU stand-off over Ukraine (Gurina 2015). For his part, Vladimir Putin has spoken of the way Eurasian economic integration can create the conditions to 'change the geopolitical and geo-economic configuration of the entire continent', creating an 'undoubted positive global effect' (Putin 2011a).

But perhaps the most ambitious aspect of the EAEU is the attempt to embark on an EUstyle integration project. Sergei Glazyev, an advisor to Putin on matters pertaining to Eurasian integration has confirmed that the EAEU is 'following the general contours of European integration' and guided by the pragmatic objective of increasing economic competitiveness by 'ceding sovereign rights' and steadily deepening integration and harmonizing national laws (Glazyev and Tkachuk 2015, p. 61, 79). Both the Kazakhstani and Russian presidents have used key-note speeches on Eurasian integration to draw parallels with the EU and hint that this is indeed the model the EAEU is attempting to follow (Nazarbaev 2014b; Putin 2011).

It is against this background that a number of scholars have begun to paint a more optimistic picture of Eurasian economic integration (Dutkiewicz 2015; Dragneva and Wolczuk 2012a; Libman and Vonkurov 2012; Sakwa 2015). The EAEU has been described as bucking the trend of second wave regionalism in its efforts to imitate the EU and pursue 'deep integration' and 'institutionalisation' (Dragneva and Wolczuk 2012a: 220) and as an 'EU-like institution', working to lower trade barriers and harmonise legislation and then, at its later stages, attempt political integration (Gvosdev and Marsh 2014, p. 188). Other studies have pointed to the inevitability of economic integration in a region where economic life was once highly interdependent. Libman and Vonkurov use a 'U shape' analogy to describe the particular holding-together pattern of post-Soviet integration, where high levels of interdependence in the Soviet system made way for disintegration and subsequent reintegration (Libman and Vonkurov 2012). The implication is that the costs of disintegration outweigh the costs of integration, leaving regional leaders with little choice but cooperate with their regional partners.

Taken together, the progress of the EAEU and the rhetoric surrounding it lend credence to the idea that what is being attempted is nothing short of transformative integration not only economic transformation but potentially political transformation too, as competition between member states, the effect of supranational institutions and even unintended consequences lead to ever greater integration and sovereignty pooling.

\section{THE ANALYTICAL FRAMEWORK}

Assessing the potential of an integration project in its early stages of development is no easy task, and this is particularly true for the EAEU with its relatively short track record (Dragneva and Wolczuk 2012a, p. 211). Economic indicators for the Customs Union in 
the period 2010-2015, for example, need to be understood in the context of volatile international circumstances and offer little insight into the potential of Eurasian economic integration. Any analysis of production levels and trade volumes between member states, 2010-2015, must take into account the fall in international commodity prices (in particular for oil and gas), the effects of the global financial crisis (in particular the economic contraction and then expansion, 2010-2012) and the on-going effects of economic sanctions imposed on Russia following the annexation of Crimea as well as Russia's own counter-sanctions. In short, and despite studies on the EAEU's viability in terms of economic transactions (Blockmans et al. 2012), the economic outcomes of integration to date remain, at best, unreliable.

In addition, there is a great deal of uncertainty surrounding the EAEU in terms of functionality, reflecting the success of member states in moving from Customs Union to full economic union in only five years:

'At the moment what we have is a very embryonic institutional design. We do not know exactly how it will work' (Interview, Russia, 2014).

The recent additions of Armenia and Kyrgyzstan will undoubtedly complicate the picture in the short-term, as both states harmonize tariffs and legislation and as EAEU operating procedures are refined and developed.

These points relate to the bigger problem of selecting an appropriate theoretical framework for analysing the EAEU. In short, there is no single approach to understanding regional integration. It is a pluralistic field driven by competing theories that work on different epistemological and ontological premises. Regional integration is typically described in very different ways by different researchers, depending on the particular approach they take.

However, for the purposes of this article, where the main research question relates to the dependent variable - what kind of integration? - the analytical framework becomes clearer. This is even more the case when we consider those high-level statements on the EAEU that stress its 'transformative' goals. By any objective measure, Eurasian economic integration is an ambitious project, seen in terms of the official rhetoric but also the EAEU's official statutory aims of achieving the four economic freedoms (free movement of goods, services, labour and capital) and harmonizing economic and foreign policy. As noted, scholars have highlighted the unusual way Eurasian integration appears to be following the path of first wave integration - a path largely shunned by regional integration organisations since the formation of the EU.

In many ways, 'transformation' is the key concept that divides the European experience of integration from all others. It is also the key distinction between theoretical approaches. According to Schmitter (2004), himself a first wave integration scholar, all theories of regional integration can be separated along ontological lines according to the degree to which they emphasise a transformative or reproductive process. Transformative integration, as seen in the case of the EU, 'transforms' the nature of 
member state sovereignty as well as the relations between member states. Reproductive integration, in contrast, simply 'reproduces the characteristics of its participants as well as the interstate system of which they are a part' (Schmitter 2004, p. 47).

As such, neo-functionalism is an obvious choice of analytical framework to guide the empirical analysis in what follows, albeit with the need to consider one or two additional intervening variables important in the context of Eurasian integration (see below). Essentially, neo-functionalism, as a theory, describes the process of transformative integration where, after initial union, successive conflicts present member states with critical junctures and the choice to either increase or decrease their integrative efforts. According to neo-functional theory, the costs of disintegration and 'spill-back' are too prohibitive, leaving the option of 'spill-over' and the expansion of tasks the only viable option for member states.

Spill-over is the mechanism for deepening integration and includes the expansion of integration to new sectors as well as the rejuvenation of existing sectors (Schmitter 1969). In short, it refers to a process whereby member states, having agreed on collective goals for a variety of motives but unequally satisfied with their attainment, attempt to resolve their dissatisfaction either by collaboration in another, related sector (expanding the scope of commitment) or by intensifying their commitment to the original sector (increasing the level of mutual commitment) or both (Schmitter 1969, p. 162).

Nye (1968), another first wave integration scholar, talks of the measurable indicators of spill-over, such as the growth of key institutions, the stimulation of private sector organisations, attitudes and public opinion; the influence on government behaviour, including decreasing levels of corruption; and geographical extension. Nye also notes that growing 'politicisation' is a sign of progress on the path to union (Nye 1968, p. 410-422). Politicisation happens when the controversial nature of decision making increases, leading to a widening of the audience or clientele interested in integration (Schmitter 1969, p. 165-66). When politicisation reaches a level where it jeopardizes their tenure in office, national governments prefer greater task expansion to contraction (Schmitter 2004, p. 50-51).

According to neo-functional theory, the key enablers of spill-over are supranational institutions and their interaction with other actors. Supranational institutions are not background factors in the integration process, but are interested agents, with their own resources and power able to push the integration processes (Lindberg 1963). They are important independent, authoritative agents, necessary for overcoming the high-levels of mistrust that naturally exist between member states (Schmitter 2004, p. 50).

Ernst Haas, probably the most important first wave integration scholar identified supranational institutions as a necessary condition for transformative integration (Haas 1964), able to unite with vested economic interests, such as non-state actors and the business community to create their own integration agenda (Haas 2001, p. 23). Even the rival inter-governmental approach to EU integration ascribes an important place to 
economic interest groups, using supranational institutions and their own governments to push for integration (Moravcsik 1998, p. 6-7). In short, this kind of transformative integration has been described as 'attacking the castle of national sovereignty by stealth', where interest groups act as mercenaries and technocrats as agents within the castle walls to 'quietly open the gates' (Nye 1968, p. 381).

However, the neo-functional framework is not without problems. Neo-functional theory, as an explanation of EU transformative integration has a chequered history. Not only has been declared obsolete on several occasions, but first wave integration theorists were already noting a serious mismatch between rhetoric and reality in non-European integration projects as early as the 1960s. Nye, for example, observed that the most prevalent form of regionalism in less developed areas is an ephemeral expression of the superstate sense of community without any significant restructuring of interests. In other words, 'token integration'. (Nye 1968, p. 377). For his part, Haas found it unlikely that the dependent variable of system transformation could happen beyond the European site (Haas 1964).

Part of the problem with the neo-functional framework is that the narrow focus on institutions and non-state actors does not credit the importance of other background factors. Certain intervening variables, which act as facilitators and inhibitors and which combine to affect the prospects of deep, transformative integration, need to be taken into account. This was a point that became clear to first wave integration scholars by the 1970 s, coinciding with the slow-down in the EU's own integration efforts.

The importance of identity, for example, came to the fore during the 'empty chair crisis', 1965-1966, when the French nationalism of Charles de Gaulle temporarily halted European integration. The existence of a regional ideology or identity as well as shared values and beliefs among member states may be insufficient to bring about transformative integration, but 'insufficient does not mean unimportant' (Nye 1968, p. 423). In retrospect, it has been noted that neo-functionalism may have underestimated the role of resistance from national authorities (Schmitter 2004, p. 56).

The same can be said of the importance of the international context or exogenous factors, that include regional economic dynamics but also the extent to which other actors outside the region will 'help or hinder' integration (Nye 1968, p. 415). In some cases, the international context facilitates integration, forcing member states regardless of their original intentions - to adopt common policies vis-à-vis nonparticipant third parties (Schmitter 1969, p. 165). In either case, the role of 'external shocks' as either inhibitors or facilitators was also an area that neo-functionalism failed to adequately consider (Schmitter 2004, p. 56).

It is in view of these points that the broad framework of neo-functionalism can be useful for understanding Eurasian economic integration. As detailed in the material that follows, to understand the kind of integration the EAEU is currently attempting, and by extension the factors that may enable or impede the EAEU's transformative goals, attention must be given to the role of identity and international factors as important 
intervening variables, along with the important the role of institutions and non-state actors. This focus on institutions, identity and the international context or exogenous factors provides a clear framework to approach the EAEU.

This framework also fits the implicit logic found in recent literature on the EAEU, where there is a palpable element of teleology, in particular those attempts to go beyond simplistic realist explanations based on geo-politics and power in the international system. As outlined in the previous section, this teleology is based on an assumption that the costs of disintegration far outweigh the costs of further integration, and that more integration will almost certainly follow (Dragneva \& Wolczuk 2012, p. 221; Dutkiewicz 2015, p. 2). This assumption - that integration is largely unavoidable in Eurasia - is also reminiscent of assumptions found in neo-functionalism, where the choice for more integration is viewed as the most rational.

\section{THE EURASIAN ECONOMIC UNION: INSTITUTIONS}

One of the most significant moments in the development of the EAEU has been the creation of an institutional framework able to push the integration agenda. This not only includes the Customs Union (2010) but also the Eurasian Economic Commission that began working in 2012 with the express aim of ensuring the functioning and development of the EAEU. In fact, the Eurasian Commission is the first supranational institution to appear in almost 25 years of post-Soviet integration, representing a notable achievement in its own right and a strong signal of intent from EAEU founding states. As previously outlined, the prospects of deeper integration, according to the neofunctional approach depends to a large extent on the willingness of national governments to delegate sovereignty to 'supranational' institutions and, in turn, the ability of these institutions to work with vested interests, notably economic actors, to push the integration process forward. As elaborated in this section, despite successes, the EAEU faces significant barriers on both counts.

\section{The Eurasian Economic Commission}

The Eurasian Commission consists of two main bodies - the Commission Council and the Commission Board. The Commission Board comprises three minsters from each member state - 14 at the time of writing, but 15 when Kyrgyzstan finally joins and their representation increases from two to three minsters. The Head of the Commission, presently Viktor Khristenko (Russia), is also a member of the Board but without a cabinet post (the only minister without a portfolio). The Commission Council is the higher body of the two and is represented by one deputy prime-minister from each member state. The Council convenes to negotiate and consult when necessary, while the Board works on a permanent basis. 
In terms of functioning, there are 23 departments under ministerial control in the Commission each divided among the members of the Board, with the emphasis on 'equality' and an even division of labour between national representatives. Each department covers an area of integration and economic activity, coordinating with corresponding government bodies in member states. The Eurasian Commission is also involved in international cooperation and, as already mentioned, there is a general acknowledgement that the EAEU will continue to look for new members and expand.

Despite some criticism that the Commission is a Russia-dominated institution, in particular since it is based in Moscow with Russian as the working language and with a predominance of Russian support staff (Dragneva and Wolczuk 2012b, p 7), the Commission is balanced by the absence of any weighted voting that would favour Russia (a problem with EurAsEC) meaning that consensus decision making is the norm, although there is limited use of Qualified Majority Voting (QMV) for low-level decisions. In addition, the first ever meeting of the Commission Council in January 2013 resolved to establish representative offices in Belarus and Kazakhstan and, overall, the Commission is characterised by highly professional staff, committed to the task of integration:

'Although we all are representatives of our own countries within the Commission, we do not represent the interests of our countries... we all stand for the common interests of integration' (Interview, Eurasian Commission, 2014).

However, the Eurasian Commission from the outset was designed to be a much less ambitious supra-national body than the official discourse surrounding the EAEU suggests, reflecting the fact that member states were not prepared to give it anything more than limited competencies (see next section). Although the Eurasian Commission itself states that Commission decisions are 'binding on the territory of the EAEU member states' (EAEU 2015b) this is more than a little deceptive.

The first point to note about the Eurasian Commission is that it is more intergovernmental than supranational. All Commission members are delegates nominated by national governments and whatever decision the Commission makes, at this stage, is only the result of consensus between member states. The highest body of the EAEU is the Supreme Council which comprises member state presidents, not the Commission, and as such all decisions taken by this 'supranational' institution are open to veto. Even if the professional Commission ministers put their national allegiances to one side and try to push the path of integration for the 'greater good', the reality is that all important decisions are passed up the chain of command, first to the Commission Council in the form of national government deputy prime ministers, and then, if no agreement is found, to the Supreme Council. As one interviewee noted:

'Although the supranational element of the EAEU could be extended in the future, the current reality is one of hierarchy' (Armenia 2014). 
The second and no less important point with the Commission is that there are few, if any, mechanisms of enforcement. Unlike the EU, where the European Commission's directives are mandatory for all member states, the Eurasian Commission has the power to monitor, make suggestions and issue orders, but the only further option is to refer the case to the Eurasian Court - created in 2000 and itself a remnant of EurAsEC - which has no enforcement powers. In any case, the Commission must notify the EAEU Supreme Council once a case is referred to the Eurasian Court, and this opens up opportunities for behind the scenes negotiations among EAEU heads of state.

A good example of the weakness of the Commission can be seen in its inability to tackle monopolies. The Commission has repeatedly flagged examples of unfair competition, such as the price of cross-border air and train tickets, as a barrier to the principles of free-trade, but has been unable do any more than suggest the creation of working groups to further study the problem (Eurasian Commission 2014b, 2014c). As noted by the former Eurasian Commission deputy Director of the Department for Competition and State Procurement Policy, Boris Parsegov, the Commission, having identified unfair competition, can write a request and issue orders to national antimonopoly agencies, but what happens after this point is already beyond the remit of the Commission (Bekmatambetova 2014).

With the extent of cartels and monopolies in member states, in particular in Armenia and Belarus, it is difficult to envisage how the EAEU's watered down supranational institutions can make an impact. Armenia, for example, has a long-term problem with commodity based cartels (BTI 2014, p. 15) which emerged as a result of the country's conflict economy and closed borders with Turkey and Azerbaijan. In this case, it is doubtful that the Moscow-based Commission with its limited powers can succeed where successive national governments have failed. The Commission's Conference on antitrust regulation and competitiveness in Minsk in 2014, for example, noted how sustainable growth is 'inextricably linked' to competition and proposed that Belarus introduce legislation to 'control state involvement in entrepreneurial activities' (Eurasian Commission 2014d). However, as the Belarus economic model is heavily oriented to state involvement and state subsidies, a large part of the economy is in essence a state-run monopoly.

In the absence of genuine powers to enforce decisions, the main challenge for the Commission is to try to harmonise diverging national interests and achieve consensus on issues pertaining to the common market, as without full agreement at the national level, the Commission cannot function as a supranational organ. But with stark differences in economic models, priorities and sheer size between member states (see next section) achieving consensus is no easy task, confirmed by the fact that the EAEU is already following the path of multi-speed integration.

Aside from a general acknowledgment that Belarus lags behind other member states and will require more time to liberalise its economy, each of the four economic freedoms are developing (or not) at different speeds. The free movement of services and capital are 
unlikely to be realised in the short-term. Kazakhstan, for example, negotiated exemptions from liberalising transport services to protect domestic carriers, meaning there is no common transport market at present. There is still no common energy market, meaning no non-discriminatory access to the Russian gas transit system for Belarusian and Kazakhstani suppliers. The free movement of labour is a problem under discussion, in particular residency rules that limit the ability of entrepreneurs to open or relocate businesses and bring in personnel from other member states and even the free movement of goods has restrictions. Sensitive goods, such as alcohol and pharmaceuticals are still subject to restrictions as member states are unwilling to fully open their markets to competition with these goods. Monetary policy is another area under discussion, although a recent meeting of the EAEU Supreme Council in May 2015, Putin sounded a note of caution: 'we are fully aware that this is a matter for the future. Nobody here is going to get ahead of themselves' (Putin 2015).

\section{Actors and integration}

The existence of multi-speed integration so early on in the EAEU's development has been noted as a strength, as too the 'hierarchic' command structure with its relatively under-powered Commission. At present, member states are able to commit to as much integration as they are ready for, while the combination of weak institutions at the national level and the absence of effective democratic checks and balances mean that EAEU leaders can make quick decisions without the need for lengthy public or parliamentary consultation. The overall institutional design of the EAEU, with real decision-making located in the Supreme Council means that the heads of state can decide to take integration in different directions, to develop stronger supranational bodies in the future, should that avenue become expedient:

'In my opinion, the established institutional form of the Customs Union is actually quite flexible - all the countries move towards each other by small steps' (Interview, Russia, 2014).

However, the EAEU model, based on presidential 'manual control' has obvious drawbacks. Not only is the fate of the entire integration process dependent on the chemistry that exists between national leaders (and their ability to retain presidential power) but there is significantly less room for other actors in the integration process to play their role. In essence, the EAEU has a two-way interaction problem, where the Commission is too weak to effectively push the integration process forward and nonstate actors too weak or too cautious to use supranational institutions to lobby their interests - a crucial limit on the ability of the EAEU to achieve 'transformative' integration.

A generalised indication of the extent of this two-way interaction problem can be seen in comparative measures of political and economic pluralism in EAEU member states. For example, Belarus, Kazakhstan and Russia are each rated 'not free' by the US based 
democracy advocacy organisation Freedom House in their 2015 survey, scoring close to bottom on measures of civil liberties and political rights (Freedom House 2015). Moreover, the direction of development suggests a downward trend, with Belarus, Kazakhstan and Russia tightening legislation governing civil society in recent years, in particular NGO funding, with pressure on Armenia and Kyrgyzstan to follow suit (IPHR 2013).

In terms of economic indicators, EAEU member states fare no better. Kazakhstan's economy was rated as 'moderately free' on the Heritage 'Index of Economic Freedom' (IEF, published by the Wall Street Journal and the Heritage Foundation) and the $69^{\text {th }}$ freest economy out of 178 countries, mainly due to relatively low taxes and investment freedom. Russia's economy (ranked 143) was rated 'unfree' and Belarus (153) as 'repressed', giving an indication of the problems faced by the business community, where state intervention, corruption and weak rule of law are the norm rather than the exception (IEF 2015).

The ability of businesses to lobby, in particular at the regional level and in particular in Russia and Kazakhstan, should not be underestimated. In the 1990s, most businesses developed close ties with regional administrations (Libman and Vinokurov 2012, p. 102) and in many ways the development of the EAEU is one outcome. However, the notion that the business community or any societal actor can join forces with the Eurasian Commission and push their shared integration interests, or in the words of Haas 'rely on supranational institutions rather than their own governments to realise their demands' (Haas 2001, p. 23) is erroneous. Leaders in EAEU member states, it should be noted, continue to be wary of pluralism and sources of independent economic power.

For its part, the Eurasian Commission is acutely aware of the problem:

'We believe that the level of the involvement of all the subjects who have their interests is not sufficiently high. In comparison with the EU, here, business has fewer chances to be heard.' (Interview, Eurasian Commission, 2014)

Since its creation in 2012, the Commission has tried to involve the business community through various Consulting Committees under the aegis of the Commission Board. The Department on Financial Politics, for example, has two Committees, one on Taxation Politics on Financial Markets and these Committees invite representatives of the business community to participate in discussions and give their recommendations. Forums are also increasingly used by the Commission to involve both the business community and state structures in the discussion of important economic issues, where all sides have a chance to express their concerns and make proposals, summarized in the form of a Forum Resolution at the end. In addition, the Advisory Council on the Eurasian Commission - the Belarus-Kazakhstan-Russia Business Dialogue - held its first session in Moscow on 20 March 2013 (Eurasian Commission 2013). The Commission has also made important advances in developing Regulatory Impact 
Analysis (RIA) procedures, meaning supranational laws are considered in terms of their effect on the business community (Eurasian Commission 2014e).

However, there is an opinion that the Commission has yet to reach out and to effectively promote and explain its activities. The RIA procedures, for example, only envisage the creation of working groups to consider the impact of legislation on the business environment, not their social impact (Eurasian Commission 2014e), and with the absence of a legislative dimension and significant public involvement, the EAEU is very much a top down process lacking a solid societal base.

In fact, the discussion on creating a Eurasian Parliament has so far created a strong, negative reaction. On 4 October 2012, exactly 12 months to the day after Vladimir Putin published his landmark Eurasian integration article in the Russian-language daily Izvestia, Russian State Duma speaker Sergei Narishkin, published his own article in the same newspaper speaking of the desirability of a Eurasian parliament to coordinate Commission decisions with national legislatures and to expand public involvement with the project (Narishkin 2012).

But, to date, there is no agreement on either its desirability or format. There are fears that a directly elected parliament will see the asymmetry of the Union reflected, meaning a majority of seats for Russia, while nationalists in Kazakhstan reacted angrily to the idea of a Eurasian Parliament as a threat to sovereignty, prompting Nazarbaev to issue the first of a number of public statements underlining his intention to leave the EAEU, should a threat to sovereignty arise (Guzenkova 2013, p. 25). As such, the project of a Eurasian Parliament remains on the backburner:

'It is unlikely that there will ever be a Eurasian Parliament or any kind of democratic participation of the population to decision-making' (Interview, Belarus, 2014).

The sensitivity to overtly political institutions reflects the deep discomfort, in particular in Kazakhstan, at any attempt to politicise the integration process. It is no accident that the title Eurasian Economic Union and not just Eurasian Union was chosen as the official name of the project or that one of the key professional principles of the 'supranational' Eurasian Commission is the 'avoidance of politicization' (EAEU 2015b). Not only does this contradict the spill over process theorised by neofunctionalists, where successive crises and increasing politicisation lead to greater integration, but in many ways the idea that it is possible to achieve meaningful economic integration without politicisation is perhaps the most ambitious EAEU goal of all.

\section{TOWARDS EURASIANISM?}

The appearance of the EAEU in 2015 is a great deal more modest when viewed diachronically over the entire post-Soviet period. The institution of the Eurasian 
Commission, for example, did not appear in 2012 as a hard-earned response to a succession of crises which forced member states to cede more sovereignty for the purposes of deeper integration. Rather, the Eurasian Commission, along with the Customs Union were part of older plans that needed time to realise. The CIS Conceptions of an Economic Union treaty, for example, signed in 1993, envisaged a Customs Union while the formation of EurAsEC in 2001 saw proposals for a Eurasian Commission to promote original CIS economic integration goals (Sakwa 2015, p. 16).

Rather than spill over, the appearance of the EAEU is more like a delayed reaction to the idea, accepted at an earlier date, that shared problems require collective action. There is no question that the on-going effects of the 2008 global financial crisis have pushed regional leaders to realise older integration commitments, but as discussed below, the global economic down-turn is just one of a number of shared, long-term problems facing EAEU member states.

In essence, EAEU member states, notably the founding states of Belarus, Kazakhstan and Russia, hold similar views on their own circumstances that allow us to talk in general terms of a shared 'Eurasian identity', which in a number of areas sees a converging outlook to region-building as well as a similar application of a self/other perspective (Neumann 2003, p.160). As argued in this section, although this shared identity offers a partial explanation for Eurasian economic integration, at a deeper level identity politics also explain why integration has taken so long and why reproductive, as opposed to transformative integration is the only real option.

\section{Eurasian identity?}

The first area where this converging outlook and self/other application is visible is in the acknowledgement that national economies must be modernised in order to increase competitiveness and to prosper in the globalised economy, but in a gradual way that avoids economic shock and any resultant instability. As such, the whole idea of the EAEU is that it is better to first work with 'ours' - a small group of post-Soviet states with shared history, a common language and a similar elite with a shared Soviet socialisation - than to plunge head first into the global economy. Kazakhstan in particular champions this 'stepping stone' approach where 'Eurasian' modernisation is viewed as a means to greater integration in the global economy, in line with Kazakhstan's commitment to stability.

Another area where Belarus, Kazakhstan and Russia appear to share a converging outlook and self/other application is in a geo-economic sense. For each EAEU member state, China in the East and the EU in the West are seen as strategic partners in certain areas, but as strategic competitors in others. As such, an important component of Eurasian integration includes 'defensive regionalism' and trade diversion in order to protect domestic producers. Russia's interests in this area revolve around tariffs to protect key manufacturing sectors, such as automobile and aircraft manufacturing 
industries. For Kazakhstan, the inclusion of Kyrgyzstan - essentially an 'offshore' for the re-export of Chinese goods - is a step to protect its domestic market.

Finally, a by no means unimportant aspect of a shared identity is seen in the security sphere. Regional economic integration has always had a security aspect, but for the EAEU there is a growing realisation that the region is particular prone to instability. NATOs phased withdraw from Afghanistan will likely pose future challenges in Central Asia, but the fear of 'colour revolution' and regime change in EAEU member states is palpable, in particular following events in Ukraine in 2013/2014:

'There is also a widely-shared view that the 'new' Ukraine's pro-Western orientations have led the country to chaos. Here, a government's overthrow is seen as a catastrophe. Hence Eurasian integration is perceived as a remedy against the threat of a Crimean scenario' (Interview, Belarus, 2014).

However, identity as a driver for integration should not be overstated. At best, identity offers an explanation for converging interests between member state leaders at this present juncture and a reason why Eurasian integration received the fresh impetus when it did. At a deeper level, identity and Eurasian integration are much more complex and actually present a barrier to transformative integration, and nowhere is this more evident than in the divergent views of 'Eurasianism' in each member state.

Putin's advisor on Eurasian integration, Sergei Glazyev, for example, has highlighted the pre-existing ideological foundations of Eurasianism, including shared cultural, historical and even political traditions as something that sets the EAEU apart from similar integration projects around the world (Glazyev and Tkachuk 2015, p. 61). In particular, Glazyev singled out the contribution of Lev Gumilev, a Soviet intellectual (1912-1992), as particularly important for the present project. Gumilev, it should be noted, is one Eurasian philosopher who commands the respect in both Russia and Kazakhstan. Putin directly referred to Gumilev in his 2012 address to the Federal Assembly (Putin 2012) while Nazarbaev has long held an affinity with this thinker. In May 1996, Nazarbaev signed a presidential decree to rename the Akmolinskii University in Astana the 'L.N. Gumilev Eurasian National University' in honour of the philosopher (Nazarbaev 1996).

However, Gumilev did not write about economic integration. He is also one of many Eurasian thinkers, reflecting the fact that Eurasianism is a polysemantic, multivalent concept that is open to interpretation (Laruelle 2012). But, the problem with the Eurasian concept lies with one particular interpretation termed Russian 'neoEurasianism' associated with Aleksandr Dugin and others, which views economic integration strictly in terms of restoring Russia's 'great power' status. Rather than a liberal economic project, Eurasianism fits a Russian nationalist preoccupation of limiting reliance on the west, including western values, and creating a multi-polar world, with Eurasia, under Russia's leadership, representing one of these poles. 
From this perspective, Eurasianism is not only a contested concept, but a divisive one, closely associated with Russian nationalism. In the context of presidential 'manual control', its influence on the integration process may be negligible at present, but it none the less raises concerns in other EAEU member states, in particular in Belarus and Kazakhstan, that economic integration could potentially morph into an entirely different project:

'Eurasianism is an invention imposed by Russia, one that we don't quite like here. Unless people are paid to support it' (Interview, Belarus, 2014).

In addition, the plans for expanding the Eurasian Union have a weak Eurasian logic at present and do indeed appear to be driven more by Russia's own geopolitical interests. The limits of Eurasian Union expansion, according to the Eurasian Commission are those places where Russian is either a first of second language (Interview, Eurasian Commission, 2014), but this has not stopped the EAEU establishing contact with a coterie of out-of-region states with close ties to Russia, such as Vietnam and Egypt. Syria, a high-profile Russian ally in the Middle East has been repeatedly linked with the EAEU, despite the on-going civil war. In July 2015, during a visit to Moscow, the Syrian prime minister revealed that his country was holding talks on EAEU membership (RIA 2015).

As mentioned below, the question of expanding the EAEU, how fast and in what directions draws a range of, at times, contradictory responses from member states. Within each member state there is a feeling that there is a choice between either widening or deepening the integration process and that, if forced to choose, priority should be given to the latter. Kazakhstan, for example, has stressed the 'economic only' aspect of integration, with many in Astana supporting a gradual approach to expansion, extending membership only to those countries that are competitive and which bring economic 'value added' to the EAEU. Although, there is an opinion in some member states that both Kyrgyzstan and Tajikistan should be incorporated into the EAEU, as unlike European post-Soviet republics, they do not have an alternative, there is little support outside of Russia for 'exotic' members, such as Syria.

In the absence of agreement on the pace and direction of expansion and what constitutes Eurasian identity, the conclusion drawn by many is that the EAEU is already a great deal more politicised than many member states would like. The expansion of the EAEU to include Armenia in January 2015 is a case in point. Without a shared border with any EAEU member state and with hostile relations with neighbouring Azerbaijan and Turkey, Armenia's inclusion drew reservations from both Belarus and Kazakhstan. Belarus was concerned that Armenia's transition period, granted to harmonise the latter's existing WTO tariff commitments with the Customs Union would give Armenian producers competitive advantage over Belarus producers. Kazakhstan was concerned that Armenia's inclusion may complicate Astana's good relations with Azerbaijan and Turkey. However, there was a perception that Moscow wanted to 
reward Armenia for choosing Eurasian over European integration and to strengthen Russia's position in the region:

'Why is Armenia pursuing membership of the Customs Union? ... Russia wishes to increase its influence in the South Caucuses, in particular following the signing of the [Association] Agreement between Georgia and the EU' (Interview, Armenia, 2014).

Armenia's position as a 'Eurasian' nation is also open to question. Despite the creation of a Ministry for international integration and reform in November 2014 in order to speed up EAEU membership, in the period 2009-2013 Armenia was busy preparing for integration with the EU. Armenia even has a parliamentary committee for EU integration in the present parliamentary convocation, showing the suddenness of the country's foreign policy U-turn. The position among the Armenian elite and public concerning integration with Russia is largely pragmatic, with a realisation that Russia has a strong say in the country's economic development and security. But, many Armenians consider their nation European not Eurasian and the choice of the EAEU, either as a civilizational choice or as an integration project is not considered 'progressive'. For some experts residing in Armenia, the rejection of the EU Association Agreement threatens to undo positive efforts to tackle corruption and modernize the economy (Roks 2014) and opinion-poll data shows a majority of Armenians favour deepening relations with both the EU and EAEU (Civilitas 2014).

\section{Regime identity}

In some ways, EAEU integration is different to earlier CIS integration in the sense that it has already achieved a great deal more. However, a certain truism still remains - the degree to which leaders wish to see integration work is a function of how they think it will impact national sovereignty (Olcott et. al. 1999, p. 22). One of the reasons why sovereignty is guarded so tightly by member state elites is that their political survival depends on their ability to remain 'sovereigns', and to maintain tight control over the state. This is the reality of authoritarian integration. But for smaller member states which in the context of significant asymmetry means all EAEU members except Russia - integration is a fine balancing act, where either too much or too little of it poses a direct threat to the power of incumbents.

In Armenia, Belarus and Kazakhstan, the choice of Eurasian integration is an acknowledgement that Russia is an important but also unavoidable partner. For Armenia and Belarus, regime survival directly depends on Russian subsides and security guarantees, for Kazakhstan economic prosperity and modernisation depends on continued access to Russian transit corridors and the huge Russian market of 145 million people. However, in each member state there is an acknowledgment that the benefits of the EAEU are finely balanced. Russia is seen as an opportunity but also a threat by all EAEU member states. 
The first point to note is that each member state has its own 'regime identity' that serves as the basis for legitimacy and that is an important consideration when it comes to integration. Kazakhstan's regime identity is strongly bound to ethnic Kazakh nationalism, albeit hidden in an official discourse that emphasises the country's multinational reality. According to the 2009 census, only 58.9 per cent of the population are ethnic Kazakhs with ethnic Russians comprising 25.9 per cent (Embassy KZ 2015), but this has not stopped the authorities from introducing plans to promote Kazakh language, what Nazarbaev has termed the 'spiritual pivot' of the nation (Nazrbaev 2012). These plans include a programme for increasing the number of Kazakh speakers in the country to 95 per cent by 2025 and a controversial plan to switch from a Cyrillic to a Latin script for the Kazakh alphabet. Any moves toward deeper integration that involve ceding more sovereignty must balance the ruling group's ideational commitment to Kazakh nationalism and prevent opponents outflanking them with nationalist appeals.

For Belarus, regime and state identity are both fragile and inexorably entwined. Unlike Kazakhstan, nationalism is not a core feature as much as the commitment to a 'socially oriented state', meaning that levels of state ownership and subsidies in the Belarus economy are particularly high, even relative to Kazakhstan and Russia which are also characterised by high levels of state intervention. Despite a commitment to privatisation, estimates for the Belarus economy in 2014 put the level of state ownership at around 80 per cent (Indexmundi 2014). The social contract between the Lukashenko regime and the public rules out any shock therapy and rapid economic change, and so it was no surprise that during the process of drafting the EAEU treaty, it was Belarus that was most interested in member states preserving independent economic policies and that the EAEU should be 'coordinated' or 'harmonized' without a common policy (Butrin and Netreba 2014).

But, what both Belarus and Kazakhstan have in common is a fear that too much integration will pave the way for Russian capital to dominate their respective economies. In Belarus, the 2011 financial crisis saw the Eurasian Development Bank intervene with the first of several loans designed to stabilise the economy, but conditioned on a package of reforms, including privatisation of the heavily state-owned economy. However, Belarus has so far resisted calls to undertake serious economic reform, viewing privatisation as a way for Russian capital to buy up Belarusian businesses. In January 2014, for example, Lukashenko accused Russian companies of trying to buy key Belarusian enterprises, namely oil refineries 'on the cheap' (Khodasevich 2014a).

But, Lukashenko's resistance to privatisation is less a concern with preserving the socially oriented state model and more the fear that the regime will lose control over key financial flows (Frear 2012, p. 159). At the same time, there is a fear that Russia, once in control of key enterprises, will use this position to eventually replace Lukashenko with someone more congenial to Moscow. In a speech to the Belarus Security Council in December 2014, Lukashenko identified NATO and internal dissenters as a threat to national security, but also Russia (The Moscow Times 2014). 
In Kazakhstan, there is also a persistent fear that bigger Russian companies will swallow up domestic competition, and this is an issue that is delaying the harmonisation of certain policies. In fact, Belarus president Lukashenko accused Kazakhstan of delaying the transformation of EurAsEC into the Eurasian Economic Union until the eventual date of January 2015, at a time when Belarus and Russia were pushing for the signing of the agreement in 2012 (News.ru 2012). The official reason for the delay was Astana's desire to consider the effects of economic union on small and medium business (Nasha gazeta 2012), but this was also an acknowledgment that the Kazakhstan leadership is not altogether convinced domestic producers will succeed under conditions of competition with larger Russian companies. As if to remind Kazakhstan's leadership of the need to retain as many areas of competitive advantage with Russia as possible, in 2013, the pro-business, party Ak Zhol accused 'partners' in the Customs Union of attempting to influence national legislation, in particular VAT levels (Peruashev 2013), which are significantly lower than those in Russia.

When it comes to Armenia, regime identity also establishes certain limits to integration, although Armenia is an anomaly within the EAEU. Armenia is notable for its strong ethno-nationalism in what is a very ethnically homogenous state. The conflict in Nagorno-Karabakh has served as a rallying call for all political figures, but also for those promoting closer ties with Russia. As such, Armenia retains a pragmatic view of Eurasianism. This view is grounded in Armenia's geographical reality as a 'cross-road' nation positioned between Asia, Europe and the Middle East, but also an understanding of the country's near total reliance on Russia.

But unlike other EAEU member states, the ability of ruling elites to retain power is to an extent related to their ability to protect certain freedoms. Armenia has a relatively developed civil society and a relatively pluralistic political landscape. English is more widely spoken and the level of democratic development greater. Armenia, for example, is ranked 78 out of 180 countries in terms of media freedom, compared to Russia (152), Belarus (157) and Kazakhstan (160) (Reporters without borders 2015). This puts Armenia out of step with other member states, which view Armenia's liberal civil society as a threat. In March 2014, Konstantin Kosachev, the head of Russia's Rossotrudnichestvo - a state organisation charged with facilitating CIS cooperation gave an interview in which he suggested that Armenia had too many NGOs 'agitating' for the country's EU integration (Khimshiashvili 2014) and in May 2014, the Russian ambassador to Armenia suggested that the government 'neutralise' those NGOs preventing closer relations between the two countries (Volynkin 2014). For Armenia, closer EAEU integration may come at the price of polarising political reforms and the adoption of restrictive legislation seen in the other member states.

The existence of so-called 'Eurasia-scepticism' in member states at all levels of society, including the business community and the ruling elite (Vinokurov 2014) almost from the outset of integration, reveals the difficult balancing act that EAEU leaders must strike as they seek to benefit from integration without losing key constituencies. At this 
stage, at least, there is an expectation that integration will bring net benefits to all involved, while strengthening the position of incumbents and their hold on sovereignty.

\section{EXTERNAL INFLUENCES ON EURASIAN INTEGRATION}

Regional integration does not occur in a vacuum (Nye 1968, p. 414), but is very much shaped by the international environment surrounding it. In many cases, exogenous factors serve as the immediate driver for integration and this is certainly true for the EAEU. As mentioned in the previous section, for the EAEU, a combination of international and regional economic and security concerns are pushing the integration process forward. However, regardless of the drivers for Eurasian economic integration, the central argument presented in this article is that the EAEU, at this stage, is about reproducing not transforming sovereignty. Despite the rhetoric to the contrary, the EAEU is not a transformative project comparable to the EU, and even if there was a genuine desire among member state leaders to take the EAEU down this path in the future, significant barriers remain. As mentioned in the previous section, identity issues and the fierce protection of sovereignty limit the ability of member states to realise even the modest goals of trade liberalisation.

Moreover, the external influences on Eurasian integration, when considered in the context of the Ukraine crisis, 2013-2015, serve to exacerbate long-standing coordination problems, as well as raising the costs of integration for each member state involved. Taken together, these coordination issues and rising costs reveal further barriers the EAEU must overcome, but also the way in which member states view their own commitment to the integration process, providing more support for the idea of reproductive as opposed to transformative integration.

\section{Coordination problems}

The crisis in Ukraine, sparked by the refusal of former president Viktor Yanukovych to sign an Association Agreement with the EU in November 2013 and to follow a path of closer European integration, remains an important external influence on Eurasian economic integration. Ukraine was an important trading partner with each of the EAEU founding states and so it was no surprise that Ukraine's inclusion in the project was a major objective from the outset. Even after the coup that removed Yanukovych from office in February 2014, EAEU member states had not given up hope that Ukraine would change course in the future. At the signing of the EAEU founding agreement in Astana in May 2014, Belarus President Lukashenko commented that 'sooner or later the Ukrainian leadership will understand where its happiness lies’ (NTV 2014). 
But the real issue for Eurasian integration is not so much the loss of Ukraine for the project (although this was significant), but in the manifestation of hard competition between Russia and the EU and, by extension, the US. The removal of Yanukovych and the chain of events which followed, including Russia's annexation of Crimea, conflict in the east of Ukraine and economic sanctions imposed on Russia, as well as Russia's own counter sanctions, have served to create extra pressure of the integration process. It was of little surprise that Kazakhstan President Nazarbaev - who originally suggested the idea of a Eurasian Union in 1994 - made a trip to Ukraine in December 2014 to meet Yanokovych's presidential successor, Petr Poroshenko, in an attempt to regulate the conflict. As an important leader of the EAEU with a great deal of his own political capital personally invested in its success, he also acknowledged on the eve of the trip the ability of on-going economic sanctions directed against Russia to significantly reduce the potential of the EAEU (ZN, UA 2014).

However, rather than reveal the coordination of EAEU policies toward non-participants, this apparent show of solidarity and willingness of a senior statesman, such as Nazarbaev, to fly to Kiev shows how the current international impasse is serving to exacerbate existing tensions and coordination problems. Ultimately, Nazarbaev's meeting with the new Ukrainian leadership in December 2014 was as much about securing lucrative bi-lateral trade contracts as it was about regulating the conflict, and Poroshenko's statements following the meeting left no doubt that Nazarbaev, contrary to the Russian position, fully supported the principle of territorial integrity and Ukrainian sovereignty (Forbes 2015). Kazakhstan, it should be noted, chose to abstain on the UN resolution in March 2014 calling on states not to recognise changes to the status of the Crimea region (UN 2014). Armenia, Belarus and Russia voted against the resolution.

In fact, the on-going Ukraine crisis, as well as the general volatility of the global economy has already revealed tensions between EAEU member states as well as an inability or unwillingness to coordinate policy. In February 2014, for example, Kazakhstan announced a shock 19 per cent devaluation of its national currency, the tenge, in response to a weakening Russian rouble (Lillis 2014a). This move sparked fears of a currency war and a disruptive 'beggar-thy-neighbour' cycle of devaluation, as each EAEU member state tries to gain competitive advantage for domestic producers (Rao 2014). Almost to confirm this ongoing process, in January 2015, the Belarus Central Bank made a seven per currency devaluation - the second major devaluation in a week - in response to the weakening Russian rouble (Reuters 2015a).

Tensions and coordination problems have also been particularly evident in Russia's attempt to enforce its own counter sanctions, drawn up in response to EU and US sanctions following the annexation of Crimea. In August 2014, Russia imposed an embargo on imports of meat, fish and dairy products, as well as fruit and vegetables from the USA, Canada, Norway, Australia, the EU, but also Moldova which, like Ukraine, declined overtures from the EAEU and opted to sign an EU Association Agreement. Despite this embargo, products from these countries have continued to find 
their way to the Russian market, with the authorities pointing the finger squarely at Belarus and Kazakhstan (Bondarenko 2014).

Perhaps the most illustrative example is the case of Belarusian exports following the embargo. Following Russia's ban on the import of Moldovan apples, Belarusian imports of the same product rose 24 fold (Regnum 2014). Aleksandr Lukashenko, answering allegations of taking advantage of open borders to undermine the Russian ban exclaimed 'they shut Moldova, for what? To make an example of them? ...it doesn't bring us any dividends' (Nezavisimaya gazeta 2014). In November 2014, a number of Belarusian food producers were refused access to the Russian market because the Russian food inspection agency found their products to contain harmful substances, including the metal chrome (Rossel'khoznadzor 2014). While there has been some suggestion that the Russian authorities where acting to limit Belarus's access to the market for the benefit of domestic producers, a more plausible explanation is that Russian retaliatory sanctions against the EU has led to a surge in demand for foodstuffs, with producers in Belarus and elsewhere struggling to meet quality standards in a rush to profit (Khodasevich 2014b).

Although there is no question that the Ukraine conflict has heightened tensions between EAEU member states, this is by no means new, but reflects a longer-standing pattern of coordination problems. Even before the Ukraine crisis, there was evidence that Russia's 'close partner's - Belarus and Kazakhstan - were not willing to jeopardise their own interests to support Russian initiatives. In 2010, Russia banned the import of American chicken on grounds that it failed to meet new sanitary standards established following the creation of the Customs Union, although Kazakhstan was subsequently accused of circumventing this ban by re-exporting chicken to Russia from US suppliers (RIA 2010). At the end of 2011, Russian authorities banned cheese imports from Ukraine for allegedly failing to meet quality standards in what was seen as a move to apply pressure on Kiev during a gas-pricing dispute (Bryzgalova 2012). For its part, Belarus, despite being heavily dependent on Russian subsides and despite officials suggesting they would follow Russia's suit, refused to impose a similar ban (Pravda 2012).

This particular coordination problem between Moscow and Minsk can be added to a long list of bi-lateral disputes in recent years over gas supply, milk and meat (so-called milk and meat wars), dumping allegations (sugar), and the claim that Belarus was exporting petroleum products under the guise of solvents and lubricants to avoid paying Russia the export duty. In September 2014, the Russian government submitted plans to increase taxes on the extraction of mineral deposits, including oil. This tax manoeuvre, approved by Vladimir Putin in November 2014, could cost Belarus up to one billion USD, and drew a particular vitriolic response from the Belarus president:

'Is this normal? This is an abnormal relationship ... this behaviour is often called imperial ambitions in surrounding countries, in the former republics of the [Soviet] Union' (Belta 2014). 
From 6 August 2015, following Vladimir Putin's presidential decree, authorities began destroying embargoed goods found on the territory of the Russian Federation (Fokht 2015), further raising the stakes for re-exporters in Belarus and Kazakhstan and further complicating the commitment to the free movement of goods. Overall, the inability of EAEU member states to coordinate their policies in the face of challenging external circumstances is undermining trust. Mistrust, as noted by some scholars, is key feature of regional integration (Schmitter 2004, p. 50), but for some within the EAEU, the restoration of mutual trust and confidence and the removal of fears that some member states will push their respective interests at the expense of partners was noted as a modest but important goal of Eurasian economic integration from the outset (Interview, Kazakhstan, 2014).

\section{The costs of integration}

Coordination problems between member states have been one by-product of the unfavourable international context surrounding the EAEU. However, a bigger problem is that of rising costs. If the costs of disintegration are seen by some as too prohibitive to be an option (Libman and Vonokurov 2012), then the costs of further integration may push all EAEU member states to rethink their commitment.

The costs of integration are best seen in terms of Russia's position at the heart of the EAEU. In view of the stark asymmetry between EAEU member states, Russia is the economic engine upon which the success of the project depends, but in the context of economic sanctions, instability in Ukraine and a general economic slowdown in Russia, this now looks problematic. The Russian economy is presently experiencing significant difficulties. Official statistics show that the Russian economy shrank by 4.6 per cent in the second quarter of 2015, and IMF projections suggest that sanctions linked to the Ukraine crisis may cause as much as a 9 per cent contraction in Russian GDP over the next few years (Reuters 2015b). In terms of effects, Russia's continuing economic and international problems will likely complicate both deepening and widening the EAEU.

The first point to note is a general one that the strength of the Russian economy will have a large bearing on its future expansion. Comparative studies of regionalism have long noted the dilemma faced by states in the immediate proximity which find themselves on the outside of a regional integration project (Mattli 1999). In essence, the more welfare benefits integration bestows on member states, the greater the prospects other states in the region will decide they have little choice but to join. Uzbekistan, for example, an important sub-regional power with a market size of just under 30 million people, is watching developments with the EAEU closely, and was mentioned by the Eurasian Commission as a potential candidate for membership. For this reason, it was interesting that a meeting between Vladimir Putin and Uzbek president, Islam Karimov, in July 2015 saw no mention of the EAEU. Instead, the discussion centred on another regional integration project - the Shanghai Cooperation Organisation (SCO) and it possible expansion to include India (Kremlin 2015). 
But, a bigger problem for Moscow is how to keep all EAEU members on the integration course in the context of reduced financial leverage without propping up struggling economies and paying more for the integration process. Russia, it should be noted, is now directly subsidising Crimea following its annexation in March 2014, and with sanctions in place, the opportunities for attracting foreign investment are negligible. Kyrgyzstan, for example, secured substantial funding from Russia ahead of its eventual EAEU membership and will likely require more, if it is to successfully restructure its economy to reduce reliance on re-exporting Chinese goods.

Much of the attraction of the EAEU for member states is tied to Russian subsides. Many states in the region are indirectly reliant on the Russian market but also the Russian labour market, in the form of remittances, which have suffered due to the weakening rouble. In addition, there are also more direct means through which Russia bolsters the economies of neighbouring states. Armenia, for example, was granted a gas discount in 2013 after Yerevan agreed to join the EAEU, and a further 13 percent reduction again in April 2015, after Armenia actually joined (Azatutyan 2015a). Belarus, a major CIS consumer of Russian oil, which it receives at low prices, refines and sells it on to European markets with high profit margins for Belarusian and Russian companies. Belarus also adds an export duty, generating an additional windfall for the state. In October 2014, Belarus signed an agreement with Russia meaning that all export duties generated on the 23 million tonnes of oil earmarked for Belarus in 2015 would be entered into the Belarus state budget (Interfax 2014). Informed estimates of Russian subsides to Belarus are placed at around 15 per cent of Belarusian GDP (Interview, Russia, 2014).

In an interview in January 2015, Russian finance minister, Sergei Shatalov, commented that the creation of the EAEU and the removal of tariffs was costing Russia around 30 billion USD a year in subsidies to partners (Reuters 2014), and there is no doubt that Russian money is key for EAEU success:

'The driver of economic integration in the EAEU is subsidies from Russia to other member states. Further enlargement requires more resources to be distributed by Russia to new and existing members' (Interview, Russia, 2014).

In addition to the financial costs of integration, there are also political risks for Moscow. As the international and economic climate deteriorate there is a danger that opposition groups within member states will attribute economic problems to EAEU membership, and try to mobilise popular dissatisfaction, nationalism and anti-Russian sentiment against incumbents. To an extent this is already happening. Kyrgyzstan, which has a strong pro-US and pro-Saudi lobby and a recent history of colour revolutions, has seen nationalists attempting to mobilise on an anti-integration platform in 2014 with experts predicting the next phase of destabilisation for the country due to a confluence of political and economic factors, including the effects of EAEU integration (Panfilova 2015). In December 2014, the Kyrgyz Labour Ministry commented that unemployment 
could double on joining the EAEU, as bazaars re-exporting Chinese goods are forced to close (Rehm 2015).

The situation is similar in Armenia. Armenia's economy contracted in the first half of 2015 following accession to the EAEU - the country's first decline in domestic and foreign trade volumes since the 2009 recession (Azatutyan 2015b). There is a danger that anti-government forces will mobilise popular dissatisfaction to frame Eurasian integration as at best a 'status quo' choice and push for EU integration as the only 'progressive choice' able to tackle the county's economic and social problems. To an extent this has already happened with the large-scale protests the capital Yerevan in the summer of 2015 against price rises in utilities (notably electricity tariffs) that followed Armenia's accession to the EAEU (Avedissian 2015).

Armenian society, despite its ethnic homogeneity, is divided along pro and antigovernment lines and the fact that the man responsible for taking Armenia into the EAEU, incumbent president Serzh Sarkisian, is constitutionally obliged to step down after his second term of office (2013-2018) means that there is a risk for Russia that Armenia will try to revise relations with the EU at some point in the future and balance its foreign policy vectors. Although a complete revision of Armenia's Eurasian choice is unlikely due to Yerevan's significant security and economic dependence on Moscow, as mentioned in the previous section, Armenian identity pushes it toward the European vector and countervailing views of Armenian-Russian relations do exist:

'There is a hope in some quarters that Armenia won't sign the EAEU agreement. There is also some support for EU membership and NATO membership and the withdrawal of Russia's military bases' (Interview, Armenia 2014).

Overall, the international context surrounding the EAEU has raised the costs for each EAEU member state. For Russia's partners, there is no desire to sign up to an isolationist project. One of the key measures of EAEU success identified in each member state is an improvement in the investment climate. However, available FDI figures for EAEU member states, notably Belarus and Russia show a sharp drop in the period 2010-2014 (World Bank 2015). There is also no desire among Russia's partners to give up their multi-vectored foreign policies. For Armenia, Belarus and Kazakhstan the value of the EAEU is significantly reduced if it undermines relations with third countries.

There is also the fear of Russian unpredictability that is no doubt making some member states feel uncomfortable, not least Putin's 'Crimea Doctrine' (Putin 2014b) and Russia's willingness to defend the interests of ethnic Russians living beyond the territory of the Russian Federation. In Kazakhstan, the combination of a large ethnic Russian population in the north of the country and uncertainty concerning the postNazarbaev power succession opens up the possibility of Russian intervention in the future. Reminiscent of Russia's lease of the Sevastopol naval base from Ukraine - a major factor in the annexation of Crimea - Moscow and Astana have unresolved issues surrounding the lease of the Baikonur space launch facility located in the south of 
Kazakhstan. Unable to reach an agreement, the two sides signed a three-year 'road map' agreement in December 2013, but not before Kazakhstani officials had threatened to eject Moscow from the complex (Lillis 2014b). During an awkward exchange in August 2014, Vladimir Putin appeared to question the legitimacy of Kazakhstani statehood resulting in Kazakhstani president, Nursulan Nazarbaev, again stating that Kazakhstan would leave the union, if there was a threat to the nation's sovereignty (RT 2014).

\section{CONCLUSIONS}

This article is aimed as a corrective to existing literature, both narrow realist accounts that frame Eurasian integration in terms of the expediencies of Russia's foreign policy objectives, dismissing the internal dynamics of integration and the positions of the other member states, and those studies that view ever more integration as inevitable. It does not challenge the real achievements of EAEU, as documented in other studies (Dragneva and Wolczuk 2012a; Glazyev and Tkachuk 2015), but rather points to the barriers and modest aims of the project as one intended to reproduce rather than transform sovereignty.

Comparative experience tells us that regional integration projects evolve over time and that the original arrangements at the moment of inception are subject to revision as the endogenous and exogenous circumstances of the regional organisation change.

Mercosur and Latin American integration existed on and off for the best part of 100 years before the changes to the international system and internal progress with democracy paved the way for deepening integration in the 1990s. ASEAN's famous 'informal' approach to integration and loose institutional structure was revised in the wake of the 1997 Asian financial crisis leading to, among other things, tighter control over the economic aspects of integration. The experience of Mercosur and ASEAN as relatively successful integration projects also point to the possibility of equifinality different ways to reach the same end point. In this case, EU-style integration is not the only game in town.

However, one of the biggest premises of Eurasian integration is that member states are ready to commit to nascent supranational institutions, that 'participating countries' are now 'willing to delegate some of their recently acquired sovereignty' (Glazyev and Tkachuk 2015, p. 61). What this article has shown is that this is not the case. At this juncture, member states are attempting to use economic integration to strengthen sovereignty and this is reflected in the institutional arrangements of the EAEU, but also the tensions and coordination problems that exist between them. There is no genuine willingness on the part of member states to transform relations with partners by ceding sovereignty to supranational institutions, at least not at this stage. As member states are making stringent efforts to avoid politicising the integration process, there is little way future crises can generate spill over. In many ways, this situation is exacerbated by the way member states view independent actors within their own polities. The prospects of the business community linking up with the Eurasian Commission to drive the 
integration process are unlikely to be tolerated by entrenched regimes whose main goal is to stay in power.

Moreover, this article has shown why this is the case. At present, identity politics is an important intervening variable, but one which inhibits rather than facilitates integration. The same is true of international factors surrounding Eurasian integration. Without doubt exogenous influences feature prominently in the development of the EAEU. As Vladimir Putin noted in a keynote speech in 2007: 'history has convincingly shown on enough occasions that the situation in Russia in many ways determines the situation in the surrounding countries in the Eurasian region' (Putin 2007). The success of the project will depend on how quickly the Russian economy can get back on track and if the unfavourable external economic and political circumstances improve, not least because Russia's EAEU partners and prospective members are watching this closely.

But, with western rhetoric hardening toward Russia (Giles et. al. 2015) and with little sign that sanctions will be eased or lifted in the near future, the prospect that member states may revise their integration commitments remains. As one interviewee noted: 'when they see some benefits in uniting, they unite, but if tomorrow the mutual benefits disappear, the union will fall apart' (Interview, Russia 2014). While disintegration and 'spill-back' may entail too high costs for all involved, if Russia's present economic and international problems continue then there is a real possibility that EAEU partners will use Moscow's weakness to seek more opt-outs and concessions to remain in the Union. This more probable latter option will serve to slow down integration and increase the chances that Eurasian economic integration, just like previous attempts in the postSoviet period, will fail to meet the expectations of those involved.

\section{REFERENCES}

Adomeit, H, Putin's Eurasian Union: Russia's Integration Project and Polices on Post-Soviet Space, Neighborhood Policy Paper, CIES, July 2012.

Avedissian, K, The power of Electric Yerevan, Open Democracy, available at https://www.opendemocracy.net/karena-avedissian/electrified-yerevan, 2015.

Azatutyan, Russia Agrees to Deeper Gas Price Discount for Armenia, available at http://www.azatutyun.am/content/article/26983718.html, 2015a.

Azatutyan, Armenian Trade in First Decline after 2009 Recession, available at http://www.azatutyun.am/content/article/27168394.html?utm_source=dlvr.it\&utm_medium=twitter, $2015 b$.

Belta, Lukashenko: Situatsiya s nalogovy manevrom yavlyaetsya proyavleniem imperskikh ambitsii Rossii (Lukashenko: the situation with the tax manoeuvre shows the appearance of imperial ambitions) available at http://www.belta.by/president/view/lukashenko-situatsija-s-nalogovymmanevrom-javljaetsja-projavleniem-imperskih-ambitsij-rossii-56537-2014, 2014.

Blockmans, S, H, Kostanyan and I Vorobiov, Towards a Eurasian Economic Union: The Challenge of Integration and Unity, CEPS Special Report, No. 75/December 2012.

Butrin, D and P. Netreba, Ob'edinit'sya - ne znachit dogovorit'sya (Uniting - doesn't mean agreeing) Kommersant' available at http://kommersant.ru/doc/2405918, 2012. 
Bekmatambetova, D, Kak budyt regulirovat' konkurentsiyu v EAES, Kursiv KZ available at http://www.kursiv.kz/news/details/vlast/kak_budut_regulirovat_konkurentsiyu_v_eaes/, 2014.

Bryzgalova, E, Ukrainskii syr ne rastet na pal'me (Ukrainian cheese does not grow on palm trees) Gazeta, available at http://www.gazeta.ru/business/2012/04/17/4404481.shtml, 2012

Bondarenko, M, Rossiya obvinila vlasti ES v podderzhke reeksporta zapreshchennikh produktov (Russia accused the authorities of the Eurasian Union of supporting the re-export of banned products) $R B K$ Daily available at http://top.rbc.ru/politics/16/10/2014/543fe1c9cbb20f429eb17998, 2014.

BTI, Armenia Country Report, Bertelsmann Transformation Index available at http://www.btiproject.org/uploads/tx_itao_download/BTI_2014_Armenia.pdf, 2014.

Civilitas What do we know about our foreign policy choices? Civilitas available at http://www.civilitasfoundation.org/cf/images/stories/binder5.pdf, 2014.

Dragneva, R. and Wolczuk, K, Commitment, asymmetry and flexibility: making sense of Eurasian Economic Integration in Dragbeva, R \& K Wolczuk (eds), Eurasian Economic Integration: Law, Policy and Politics, Cheltenham: Edward Elgar, 204-221, 2012a.

Dragneva, R. and Wolczuk, K, Russia, the Eurasian Customs Union and the EU: Cooperation, Stagnation or Rivalry? Chatham House Briefing Paper REP BP 2012/01, available at http://www.chathamhouse.org/sites/files/chathamhouse/public/Research/Russia\%20and\%20Eurasia/0 812bp_dragnevawolczuk.pdf, 2012 b.

Dutkiewicz, P, Introduction: EU-Ru-Asian integration? in Dutkiewicz, P. and Sakwa, R. (eds) Eurasian integration-the view from within, Oxford: Routledge, 1-11, 2015.

EAEU, Resheniya Vysshevo Evraziiskovo ekonomicheskovo soveta (Decisions of the Supreme Eurasian Economic Council), available at http://www.eurasiancommission.org/ru/Lists/EECDocs/635551006672796548.pdf, 2014.

EAEU, Free trade agreement between the Eurasian economic union and its Member states, of the one part, and the socialist republic of Vietnam, of the other part available at https://docs.eaeunion.org/sites/storage1/Lists/Documents/514cae6f-eef6-4d06-9fda96b33a390153/cab34696-031c-4238-a0fd-da7e5126065e_EAEU-VN_FTA.pdf, 2015a.

EAEU, O Evraziiskoi Ekonomicheskoi Komissii (On the Eurasian Economic Commission), available at http://www.eurasiancommission.org/ru/Pages/about.aspx, 2015 b.

Eurasian Commission, Sostoyalos' pervoe zasedanie Konsul'tativnovo soveta po vzaimodeistviyu Evraziiskoi ekonomicheskoi komissii I Belorussko-Kazakhstansko-Rossiiskovo biznes-dialoga (the first meeting of the consultative council on the cooperation of the Eurasian Economic Council and the Belarus-Kazakhstani-Russian business dialogue took place) available at http://www.eurasiancommission.org/ru/nae/news/Pages/swss.aspx, 2013.

Eurasian Commission, The 19th Session of the Board of the Eurasian Economic Commission, available at http://www.eurasiancommission.org/ky/nae/events/Pages/07-07-2014-1.aspx, 2014a.

Eurasian Commission, Ministr po konkurentsii i antimonopol'nomu regulirovaniyu EEK Nurlan Aldabergenov (the Minister for competition and antimonopoly regulations of the Eurasian Economic Commission, Nurlan Aldabergenov) available at http://www.eurasiancommission.org/ru/nae/news/Pages/10-04-2015-4.aspx, 2014b.

Eurasian Commission, V EEK vstretilis' glavy antimonopolnykh vedemostv stran TS i EEP (the head of the antimonopoly department of the TS countries and the EEP met in the EEK) available at http://www.eurasiancommission.org/ru/nae/news/Pages/14-04-2014-2.aspx, 2014c.

Eurasian Commission, Sostoyalas' 'antimonopol'noe regulirovanie i konkurentosposobnost' natsional'noi ekonomiki v usloviyakh EEP' (Conference 'Antitrust Regulation and Competitiveness of the National Economy in the Single Economic Space Environment' available at http://www.eurasiancommission.org/ru/nae/news/Pages/10-06-2014-1.aspx, 2014d. 
Eurasian Commission (2014e) Ministr po ekonomike i finansovoi politike EEK Timur Suleimenov: 'Protsedura otsenki reguliruyushchevo vozdeistviya proektov reshenii Kommissii budet vnedrena v deyatel'nost' Komissii s nachalom funktsionirovaniya EAES s 1 yanvariya 2015 goda' (The Eurasian Economic Commission Minister in charge of Economic and Financial Policy Timur Suleimenov: 'The Regulatory Impact Assessment procedure on drafts of Commission decisions will be implemented from the moment of launching the Eurasian Economic Union on 1 January 2015) available at http://www.eurasiancommission.org/ru/nae/news/Pages/15-12-2014-2.aspx, 2014e.

Fokht, E, V Rossii nachalos' massovoe unichtozhenie sanktsionnykh produktov (In Russia begins the mass destruction of sanctioned products) $R B K$ Daily available at http://top.rbc.ru/politics/06/08/2015/55c32b649a79470d911fcf8f, 2015.

Freedom House, Freedom in World 2015, available at https://freedomhouse.org/report/freedomworld/freedom-world-2015\#.Vdxn6vlVhBc, 2015.

Forbes, Prezidenti Kazakhstan i Ukrainy obsudili konflikt v donbasse (The Presidents of Kazakhstan and Ukraine discuss the conflict in Donbass) available at http://forbes.kz/process/poroshenko_blagodarit_nazarbaeva_za_podderjku_tselostnosti_ukrainyi, 2014.

Frear, M, Belarus: player and pawn in the integration game, in Dragbeva, R \& K Wolczuk (eds), Eurasian Economic Integration: Law, Policy and Politics, Cheltenham: Edward Elgar. pp. 119-138, 2012.

Guzenkova, T, Evraziiskii ekonomicheskii soyuz: otnoshenie k proektu v stranakh SNG (Eurasian economic union: attitudes to the project in CIS countries, Problemy natsional'noi strategii 1 (16), 741. https://riss.ru/images/pdf/journal/2013/1/04 .pdf, 2013

Giles, K, Hanson, P, Lyne, R, Nixey, J, Sherr, J and A, Wood, The Russian Challenge available at http://www.chathamhouse.org/sites/files/chathamhouse/field/field_document/20150605RussianChalle ngeGilesHansonLyneNixeySherrWood.pdf, 2015).

Gvosdev, N. and Marsh, C, Russian Foreign Policy: Interests, vectors and sectors, London: Sage, 2014.

Glazyev, S. and Tkachuk, S, Eurasian Economic Union: achievements and prospects in Dutkiewicz, P. and Sakwa, R. (eds) Eurasian integration-the view from within, Oxford: Routledge, 61-83, 2015.

Gurina, N, Lukashenko verit v sblizhenie ES i Evraziiskovo Ekonomicheskovo Soyuza (Lukashenko believes in the merging of Eurasec and the Eurasian Economic Union) RIA Novosti available at http://ria.ru/world/20150429/1061611656.html, 2015.

Haas, E, Beyond the nation-state, Colchester: ESPR Press, 1964.

Haas, E, Does constructivism subsume neofunctionalism? In Christiansen, T, Jorgensen, K and Wiener A (eds) The social construction of Europe, Sage: London, 22-31, 2001.

Indexmundi Belarus Economy Profile 2014 available at http://www.indexmundi.com/belarus/economy_profile.html, 2014.

IPHR, Joint statement to OSCE Human Rights Conference: Repressive NGO legislation and practice in the post-Soviet region, International Partnership for Human Rights available at http://www.iphronline.org/osce-hdim-joint-statement-on-freedom-of-association-20130927.html, 2013.

Interfax, Ves' ob' 'em eksportnykh poshlin ot prodannykh RB v 2015 godu nefteproduktov poidet v belorukkskii byudzhet (The entire volume of duties from sales by the Republic of Belarus of oil products in 2015 will go the Belarus budget) available at http://www.interfax.by/news/belarus/1168549, 2014.

Index of Economic Freedom, Country rankings available at http://www.heritage.org/index/ranking 2015. 
Embassy KZ Ethnic Diversity, Embassy of Kazakhstan available at http://www.kazakhembus.com/content/ethnic-diversity, 2015.

Kremlin, Meeting of Supreme Eurasian Economic Council, Kremlin.ru available at http://en.kremlin.ru/events/president/news/49435, 2015.

Kremlin, Meeting with President of Uzbekistan Islam Karimov, Kremlin.ru available at http://en.kremlin.ru/events/president/news/copy/49906, 2015.

Krickovic, A, Imperial nostalgia or prudent geopolitics? Russia's efforts to reintegrate the post-Soviet space in geopolitical perspective, Post-Soviet Affairs, 30 (6) 503-528, 2014.

Khimshiashvili, P, 'V krizis v razy povysilas' poseshchaemost' kursov baleta' - Konstantin Kosachev, rukovoditel' Rossotrudnichestva (in times of crisis, attendance of ballet courses increases several fold - Konstantin Kosachev, head of Russian Cooperation) Vedomosti available at http://www.vedomosti.ru/newspaper/articles/2014/03/13/v-krizis-v-razy-povysilas-poseschaemostkursov-baleta\#/cut, 2014.

Khodasevich, A, Den'gi rossiiskie, stsenarii belorusskii (Russian money, Belarusian scenario) Nezavisimaya gazeta, available at http://www.ng.ru/cis/2014-01-31/1_lukashenko.html, 2014a.

Khodasevich, A, Evraziiskii soyuz daet sboi (The Eurasian Union is failing) Nezavisimaya gazeta available at http://www.ng.ru/cis/2014-11-24/1_evrazes.html 2014b.

Laruelle, M, Russian Eurasianism: ideology of an empire, Baltimore: The Johns Hopkins University Press, 2012.

Libman, A and Vinokurov, E, Holding-Together Regionalism: Twenty Years of Post-Soviet Integration, Hampshire: Palgrave Macmillan, 2012.

Lillis, J, Kazakhstan: Currency Plunges after Months of Devaluation Rumors, Eurasianet, available at http://www.eurasianet.org/node/, 2014a.

Lillis, J, Kazakhstan: Environmental Protest Movement Growing around Baikonur, Eurasianet, available at http://www.eurasianet.org/node/67996, 2014b.

Lindberg, L, The Political Dynamics of European Economic Integration, California: Stanford University Press, 1963.

Lukashenko, A, O sud'bakh nashei integratsii (On the fate of our integration) available at http://izvestia.ru/news/504081, 2011.

Lukasehnko, A, Zasedaniya Vysshevo Evraziiskovo Ekonomicheskovo Soveta (Meeting of the Supreme Eurasian Union Council) available at http://www.kremlin.ru/transcripts/45790, 2014.

Mattli, W, The logic of regional integration, New York: Cambridge University Press, 1999.

Moravcsik, A, The Choice for Europe, Cornell University: New York, 1998.

Narishkin, S, Evraziiskaya integratsiya: parlamentskii vector (Eurasian integration: the parliamentary vector) Izvestia available at http://izvestia.ru/news/536755, 2012.

Nasha gazeta, Evgenii Shibarshin: 'pochemu Kazakhstan otlozhil podpisanie dogovora o Evrasiiskom soyuze? (Evgeni Shibarshi: why did Kazakhstan postpone the agreement on the Eurasian Union?) Nasha gazeta available at http://www.ng.kz/modules/news/print.php?\&storyid=7386, 2012.

Nazarbaev, N, Ykaz prezidenta respublika Kazakhstan o Evraziiskom universitete imeni L.N Gumileva (Decree of the president of the republic of Kazakhstan on the Eurasian University in honour of L.N Gumilev) http://www.enu.kz/downloads/ukaz.pdf, 1996.

Nazarbaev, N, 'Evraziiskii soyuz neobkhodim: my prosto obrecheny doveryat' drug drugu' (the Eurasian Union is necessary: we simply have to trust one another) in N Nazarbaev (ed) Evraziiskii soyuz: idei, 
praktika, perspektivy, 1994-1997, Moskva: Fond Sodeistviya Razvitiyu Sotsialnykh i Politicheskikh Nauk, 32-38, 1997.

Nazarbaev, N, President's Speech: New Kazakhstan Patriotism, available at http://kazakhstan2050.com/patriotism/presidents-speech, 2012.

Nazarbaev, N, Vystyplenie Prezidenta Kazakhstana N Nazarbaeva na tseremonii podpisaniya Dogovora o Evraziiskom ekonomicheskom soyuze (Speech of the president of Kazakhstan N Nazarbaev at the ceremony of the signing of the Eurasian Union agreement)

http://www.akorda.kz/ru/speeches/internal_political_affairs/in_speeches_and_addresses/page_219478 _vystuplenie-prezidenta-kazakhstana-n-nazarbaeva-na-tseremonii-podpisaniya-dogovora-oevraziiskom-ekon, 2014a.

Nazarbaev, N, Zasedaniya Vysshevo Evraziiskovo Ekonomicheskovo Soveta (Meeting of the Supreme Economic Council) available at http://www.kremlin.ru/transcripts/45790, 2014b.

Nezavisimaya gazeta, Evraziiskii soyuz ne smozhet zamenit Rossii Evropeiskii (Eurasian Union cannot substitute Russia for Europe) available at http://www.ng.ru/editorial/2014-10-20/2_red.html, 2014

NTV, Lukashenko vspomnil v Astane o poteryannoi dlya EAES Ukraine (Lukashenko recalls the loss of Ukraine for the Eurasian Economic Union while in Astana) available at http://m.ntv.ru/novosti/999177/, 2015.

Neumann, I, A region-building approach in Soderbaum, F and Shaw, T (eds) Theories of new regionalism, New York: Palgrave Macmillan, 160-178, 2003.

News.ru, Lukashenko: transformatsiyu EvrAzES pritormozil Kazakhstan (Lukashenko: The transformation of Euasec was slowed by Kazakhstan) available at http://www.newsru.com/finance/21mar2012/lukashenko.html, 2012.

Nye, J, Central American Regional Integration in Nye, J (ed) International Regionalism: readings, Boston: Little, Brown \& Company, 377-429, 1968.

Olcott, M, Aslund, A. and S. Garnett, Getting it Wrong: regional cooperation and the commonwealth of independent states, Washington D.C: The Brookings Institution Press, 1999.

Panfilova, V, The USA looking to come back to Kyrgyzstan, The New Eastern Outlook, available at http://journal-neo.org/2015/03/22/rus-ssha-stremyatsya-vernut-sya-v-kirgiziyu/, 2015.

Pravda, Belarus bozhitsya, chto budet est' ukrainskii syr (Belarus swears it will eat Ukrainian cheese) Ukrainskaya pravda available at http://www.pravda.com.ua/rus/news/2012/02/9/6958474/, 2012.

Putin, V, Speech at the XI St Petersburg International Economic Forum available at http://archive.kremlin.ru/eng/speeches/2007/06/10/1823_type84779_133777.shtml, 2007.

Putin, V, Novyi integratsionnyi proekt dlya Evrazii - budyshchee, kotoroe rozhdaetsya sevodnya (a new integration project for Eurasia - the future which is being conceived today) available at http://izvestia.ru/news/502761, 2011.

Putin, V, (2012) Poslanie Prezidenta Federal'nomy Sobraniyu (address of the president to the Federal Assembly) available at http://kremlin.ru/events/president/news/17118, 2012.

Putin, V, Soveshchanie s chlenami pravitel'stva (Meeting of the members of government) 12 February, Moscow Oblast', Novo-Ogarevo available at http://special.kremlin.ru/events/president/news/20217, 2014a.

Putin, V, Obrashchenie Prezidenta Rossiiskoi Federatsii (address of the president of the Russian Federation) available at http://www.kremlin.ru/transcripts/20603, 2014b.

Putin, V, Meeting of Supreme Eurasian Economic Council available at http://en.kremlin.ru/events/president/news/49435, 2015. 
Peruashev, A, Ak Zhol Party Continues to Advance Business Interests, The Astana Times, available at http://www.astanatimes.com/2013/02/ak-zhol-party-continues-to-advance-business-interests/, 2013.

Reuters, Interv'yu-minfin RF gotovitsya k novomy nalogovomy manevru v nefteotrasli s 2015 goda (interview-the Russian finance ministry is ready for a new tax manoeuvre in the oil industry in 2015), available at_http://ru.reuters.com/article/businessNews/idRUMSEA2C02L20140313?sp=true, 2014.

Reuters, UPDATE 1-Belarus devalues currency again to protect against Russian economic fallout available at http://www.reuters.com/article/2015/01/08/russia-crisis-belarus-currencyidUSL6N0UN17L20150108, 2015a.

Reuters, IMF says Western sanctions could cut 9 pct off Russia's GDP available at http://www.reuters.com/article/2015/08/03/russia-economy-imf-idUSL9N0OK04620150803, 2015 b.

Regnum, Eksport zapreshchennykh Rossiei moldavskikh yablok Belorussiyu vyros v 24 raza (Export of Moldovan apples to Belarus, banned by Russia, rose 24 fold), available at http://www.regnum.ru/news/polit/1847992.html, 2014.

Rao, S Rouble slide means Russia neighbours may follow Kazakh devaluation, Reuters, available at http://www.reuters.com/article/2014/02/11/emerging-russia-cis-idUSL5NOLG1BG20140211, 2014.

RIA, Onishchenko: 'khlorirovannaya kyryatina iz SSHA prodolzhaet postupat' v RF (chlorinated chicken from the USA continues to enter the Russian Federation), RIA Novosti, available at http://ria.ru/economy/20100914/275617524.html, 2010.

RIA, Prem'er Sirii: vedem peregovory o vstuplenii v Evraziiskii soyuz (prime minister of Syria: we are holding talks on joining the Eurasian Union) RIA Novosti, available at http://ria.ru/interview/20150721/1138558767.html, 2015.

RT (Russia Today), EKH: 'Neumestnye zamechaniya' Putina tolkayut Kazakhstan k vykhodu iz EAS (inappropriate comments by Putin push Kazakhstan toward an exit from the Eurasian Union), available at http://russian.rt.com/inotv/2014-09-01/EH-Neumestnie-zamechaniya-Putina-tolkayut, 2014.

Rehm, S, As Kyrgyzstan Joins Russia's Eurasian Economic Union, Not everyone's Happy, The Moscow Times available at http://www.themoscowtimes.com/business/article/as-kyrgyzstan-joins-russiaseurasian-economic-union-not-everyones-happy/520296.html, 2015.

Roks, Yu, Erevan gotovitsya k vstupleniyu v Evraziiskii soyuz (Yerevan is preparing to join the Eurasian Union), Nezavisimaya gazeta, available at http://www.ng.ru/cis/2014-11-20/6_armenia.html, 2015.

Rossel'khoznadzor, O Vvedenii Rossel'khoznadzorom vremennykh orgranichenii na postavki produktsii s nekotorykh belorusskikh predpriyatii (On the introduction by Rossel'khoznadzor of temporary restrictions on the supply of products from several Belarusian enterprises) available at http://www.fsvps.ru/fsvps/news/11705.html, 2014.

Reporters without borders, World Wide Press Freedom Index available at https://index.rsf.org/\#!/indexdetails/ARM, 2015.

Sawka, R, Challenges of Eurasian integration in Dutkiewicz, P. and Sakwa, R. (eds) Eurasian integration-the view from within, Oxford: Routledge, 12-30, 2015.

Schmitter, P, Three neo-functional hypotheses about international integration, International Organisation, 23 (1), 161-166, 1969.

Schmitter, P, Neo-functionalism In Wiener, A. and Diez, T. (eds) European integration theory, Oxford: Oxford University press, 45-74, 2004.

The Moscow Times, Belarus’ Lukashenko: Russia's Behavior Arouses Suspicion, available at http://www.themoscowtimes.com/news/article/belarus-lukashenko-says-russia-s-behavior-arousessuspicion/513476.html, 2014. 
UN (United Nations), General Assembly Adopts Resolution Calling upon States Not to Recognize Changes in Status of Crimea Region available at http://www.un.org/press/en/2014/ga11493.doc.htm, 2014.

Vinokurov, E, Evrazoskeptitsizm (Eurasiasceptism) Rossiya v globalnoi politiki, number 1 available at http://www.globalaffairs.ru/number/Evrazoskeptitcizm-16395, January/February 2014.

Volynkin, G, Rossiisko-apmyanskie otnosheniya nahoditsya na bespretsedentno vysokom urovne (Russia-Armenia relations are at an unprecedented high level), Noev Kovcheg available at http://noevkovcheg.ru/mag/2014-08/4466.html\#ixzz310qU28v9, 2014.

World Bank, Foreign direct investment, net inflows (BoP, current US\$) available at http://data.worldbank.org/indicator/BX.KLT.DINV.CD.WD, 2015.

ZN, UA, Nazarbaev nazval 'bezmozglym' tovo, kto vystupaet za vossozdanie SSSR (Nazarbaev calls those who call for a return of the USSR 'mindless'), available at http://zn.ua/WORLD/nazarbaevnazval-bezmozglym-togo-kto-vystupaet-za-vossozdanie-sssr-162452_.html, 2014.

\section{APPENDIX 1: LIST OF INTERVIEWEES}

Armenia (Yerevan)

Alexander Arzoumanian, Deputy of the National Assembly of Armenia, Deputy Chair of the Foreign Relations Committee

Richard Giragosian, Director of the Regional Studies Center (RSC)

Robert Harutyunyan, Director of Armenian Development Agency, Ministry for the Economy

Alexander Iskandaryan, Director of the Caucasus Institute

Vahagn Khachatryan, Economist, the Armenian National Council

Aram Manukyan, Deputy of the National Assembly of Armenia, member of the European Integration Committee

Aghvan Vardanyan, Deputy of the National Assembly of Armenia, Chair of the Gas Supply Committee Belarus (Minsk)

Roman Brodov, Head of foreign economic policy division, Ministry for the Economy

Vitaly Busko, Professor, member of the House of Representatives (Lower House of the National Assembly), Deputy Chairman of the Standing Commission on International Affairs

Alexander A. Filippov, Professor, Head of the Youth Affairs Department, Belarusian State University of Culture and Arts; previously expert with the Information-Analytical Centre of the Administration of the President (2010-2013)

Alexander Guryanov, Deputy-Minister for Foreign Affairs

Lev E. Krishtapovich, Deputy Director of the Information-Analytical Centre of the Administration of the President

Andrei Rusakovich, Professor, Belarus State University, Head of the Foreign and Security Policy Studies Centre, 
Vladimir Kariagin, Chairman of the Association "Minsk Capital Union of Entrepreneurs and Employers", president of the Belarusian Republican Confederation of Entrepreneurship (RCE)

Vladimir Ulakhovich, Deputy Chair of the Chamber of Trade and Commerce of Belarus

Kazakhstan (Astana \& Almaty)

Aidar Amrebayev, Head of the First Kazakhstani President Center, Institute of World Economics and Politics at the Foundation of the First President of the Republic of Kazakhstan

Tulegen Askarov, President of the Center for Business Journalism BizMedia

Ernar Bakenov, Director of the Department of international economic integration, Ministry of Economics and Budget Planning

Murat Karimsakov, President of the Eurasian Economic Club of Scientists Association (EECSA)

Nargis Kassenova, Director of Central Asian Studies Center, KIMEP University

Asan Kozhakov, Ambassador-at-Large, Ministry of Foreign Affairs

Darya Mukhamedjanova, Chief Research Fellow, Economic Studies Department, The Kazakhstan Institute for Strategic Studies (KISI)

Askar Nursha, Coordinator of Projects on Foreign Policy Issues, Institute of World Economics and Politics at the Foundation of the First President of the Republic of Kazakhstan

Dosym Satpayev, Director of the Risk Assessment Group

Alma Sultangalieva, Advisor to the Director, Institute of World Economics and Politics (IWEP) at the Foundation of the First President of the Republic of Kazakhstan

Russia (Moscow)

Rustam Akberdin, Director of the Department for Development Entrepreneurship, Eurasian Economic Commission

Askar Kishkembayev, Head of the Secretariat of the Minister for Economy and Financial Policy, Eurasian Economic Commission

Aleksandr Knobel, Laboratory of international trade, Gaidar Institute for Economic Policy

Andrey Kortunov, President of the New Eurasia foundation; Director of Russian International Affairs

Council (RIAC)

Valentina Kravchenko, Deputy Director of the Department for Financial Policy, Eurasian Economic

Commission

Dmitry Polyanski, Deputy Director, First Department of CIS countries, Ministry for Foreign Affairs

Natalya Postnikova, Senior Research Fellow, Gaidar Institute for Economic Policy

Gulnur Rakhmatullina, Minister for Economic and Financial Policy, Eurasian Economic Commission 
Amirbek Sankubayev, Head of the Financial Market Division, Eurasian Economic Commission Vitali Survillo, Vice President of All-Russia Public Organization Delovaya Rossiya Natalya Volchkova, Lead Economist, Centre for Economic and Financial Research (CEFIR) 